Volume 5 Issue 2, June 2018

\title{
The Division Of Distributable Assets To The Non-Muslim Heirs Based On Compilation Of Islamic Law
}

\author{
Siska Lestari ${ }^{1}$, Danceu ${ }^{2}$ and Sri Endah Wahyuningsih ${ }^{3}$ \\ Abstract. Inheritance issues are particularly vulnerable because they are related to \\ total assets to be distributed to the heirs. This issue often occurs and ends up in \\ court, especially concerning the issue of inheritance for non-Muslim heirs. Based on \\ the Compilation of Islamic Laws, non-Muslim heirs are not entitled to the \\ inheritance of the Muslims family. For non-Muslim heirs, this is very unfair, so it can \\ cause disunity within the family. Islam prioritizes justice and prosperity, so that \\ cases of non-Islamic heirs can be given alternative solutions by giving inheritance \\ through a mandatory will (Wasiat Wajibah). \\ Keywords: Inheritance; Non-Moslem Heir; Compilation of Islamic Law.
}

\section{Introduction}

Marriage for a man and a woman is a basic right for every Indonesian citizen. This is affirmed in Article 28 point b paragraph (1) of 1945 Constitution of the State of the Republic of Indonesia which states that: "Every person shall have the right to form a family and to continue the offspring through legal marriage".

Marriage as a human right shall be carried out in accordance with applicable law. The Government of the Republic of Indonesia has issued a policy of national development in the field of law by preparing legal unification, especially in relation to civil law and has successfully uniform marriage law in written form, namely the Law on Marriage (Act No. 1 of 1974). ${ }^{4}$

Law Number 1 Year 1974 on Marriage is a guide for Muslims in regulating marriage, besides Muslims are also guided by the Compilation of Islamic Law as contained in Presidential Instruction No. 1 of 1991 . Therefore, for the validity of marriage it must be met all the requirements contained in the legislation.

Legal marriages conducted according to religious law may mean that marriages can only be performed by men and women who are in the same religion, there are witnesses and guardians, as well as other requirements determined by their respective religions. Furthermore, marriage registration aims to order marriage administration. This marriage registration is used as valid evidence or as a form of preventive effort in the event of a conflict within the marriage. With marriage recording, married men and women must carry out their respective obligations, and marriage recording is of prime importance especially to the rights of spouses, and if something unnecessary happens in marriage, such as inheritance for spouses and children whose spouse or parent dies, living expenses or livelihoods for children, and join property when deciding on marriage or divorce, so the

\footnotetext{
1 Master of Notary's Student, Faculty of Law, Universitas Islam Sultan Agung email : ryomaechizen878@gmail.com

2 Students of Master of Law, Faculty of Law, Universitas Islam Sultan Agung email istambul 79@yahoo.com

${ }^{3}$ Lecturer of Faculty of Law UNISSULA

${ }^{4}$ Sudirman Tebba 2003 Sosiologi Hukum Islam UII Press Yogyakarta p. 104.
} 
validity of marriage will have legal consequences for husband and wife and children in the marriage matters.

From a legitimate marriage will result in legal consequences among children who are born during marriage to be lawful children. The obligation of the husband is to finance and to educate the children and his wife and seek shelter together, entitled to inherit each other between husband and wife and children with parents. The father has the right to be a marriage guardian for his daughters, and if among the husband or wife dies, then the other half is entitled to be the supervisor of the children and his/her property. ${ }^{5}$

One of the legal consequences of a legitimate marriage is the right to inherit each other between husband and wife and married children with parents. Marital relationship is the cause of the right of marriage, one of which is the right of mutual inheritance between the people involved in the marriage, namely husband, wife and children.

The definition of inheritance according to Wirjono Prodjodikoro is a matter of whether and how the various rights and duties about the wealth of a person at the time of his death will turn to the living ${ }^{6}$. In Islam, the inheritance is also called fara'idh, which means a certain part that is divided according to Islam to all who are entitled to receive it. ${ }^{7}$

The law of inheritance in Islam has an important position and receives great attention because in the inheritance distribution often causes problems for families left by the heirs, especially for the offspring children when the parents are dead. The deaths of both parents often result in problems or disputes among the heirs regarding her heritage treasures. This happens because of lack of understanding of the division of inheritance with the rules that have been set.

In Islamic law, there are obstacles to receive inheritance. The obstacles to receiving inheritance are those that result in the death of the heirs' right to receive the inheritance from the estate of the testator. The things that can be hindered are agreed by the scholars are, because of murdering, different religions, slavery, and which is not agreed by scholars is different countries. ${ }^{8}$

From the description of the above background, the authors formulated the questions about how to divide inheritance for the heirs of non-Islamic heirs based on Compilation of Islamic Law?

\section{Discussion}

The arrangement of inheritance for Muslims is governed by Islamic inheritance law. The basic principle of Islamic inheritance law is that as established in the Qur'an and Hadith of the Prophet, which is also applied to the people of Indonesia. The arrangement of Islamic inheritance in Indonesia is set out in Book II of the Compilation of Islamic Law. In Article 171 the Compilation of Islamic Law provides that: "The law of inheritance is a law which regulates the transfer of ownership rights of the inheritance of the heirs, determines who is entitled to be the heir and what part thereof".

\footnotetext{
${ }^{5}$ Mohd. Idris Ramulyo 1999 Hukum Perkawinan Islam Suatu Analisis Undang-undang Nomor 1 Tahun 1974 dan Kompilasi Hukum Islam Bumi Aksara Jakarta p. 248.

${ }^{6}$ Wirjono Prodjodikoro 2006 Hukum Warisan di Indonesia Sumur Bandung Bandung p. 13.

${ }^{7}$ Beni Ahmad Saebani 2014 Fiqh Mawaris Pustaka Setia Bandung p. 13.

${ }^{8}$ Muslich Maruzi 1981 Pokok-pokok Ilmu Waris Pustaka Amani Semarang p. 13.
} 
The heirs according to Article 171 (c) of the Compilation of Islamic Law are: "The person, who at death, has a blood relation or marriage relationship with the heir, Muslim and not hindered by law to be an heir". Heirs who are Muslims, the heirs are also Muslim, or can be said that if the parents are Muslims, then the offspring are also Muslim. It seems impossible if the child will have different religion, although the religion is a human right.

The causes of a person can be an heir is due to family relationship, marriage relationship, wala' relationship, and religious relationship (Islamic purpose). However, there are also causes that may prevent a person from receiving inheritance.

Muhammad Jawad Mughniyah in his book entitled "al Khomsah al-Mazhahib fi Fiqhiyyah" explains that the scholars agree that, there are three things that hinder the inheritance, namely: religious differences, murder, and slavery. Regarding religious differences, scholars agree that non-Muslims cannot inherit Muslims, but they differ on whether a Muslim can inherit non-Muslims? Imamiyah argues that a Muslim can inherit non-Muslims, while the four schools say: "It is impossible". ${ }^{9}$

Many problems arise in the matter of inheritance, because there are differences in viewpoint of the law in Indonesia one of them concerning inheritance, which one of the heirs is non-Muslim or because of religious differences between heirs, one party of Islam while the other religion is not Islam (non-Islam).

The legal basis as mentioned by Rasulullah through Usamah Ibn Zayd is narrated by Bukhari Muslim. Abu Daud, Tirmidhi and Ibn Majah states that a Muslim does not receive inheritance from non-Muslims and vice versa, a non-Muslim is not inherited and a Muslim. ${ }^{10}$

The intent of non-Muslims is religions, beliefs, and religious schools outside Islam. This is in the opinion of Jumhur Ulama such as Hanafiyah, Shafi'iyah and Imam Abu Daud. ${ }^{11}$

Another legal basis, expressed in the Sunnah of the Prophet which Mutafaq alaih narrated by Imam Bukhari and Muslim stated: "The Muslims do not inherit the property of the unbelievers, and the unbelievers do not inherit the property of Muslims (mutafaq alaih) ${ }^{12 "}$, mentioned also in Article $171 \mathrm{c}$ The Compilation of Islamic Law also states that: "Those who are entitled to be heirs shall be Muslims, so that if between heir and heir is not a religion, it is not mutual inheritance or heir of the heirs who are Muslims".

Judging from the viewpoint of the Compilation of Islamic Law, the different heirs of the religion have no right to obtain the distributable estate, even though the heir is the child of the parent. The existence of obstacles in obtaining the inheritance due to this religious difference resulted in the inheritance dispute between fellow heirs. Different religious heirs (non-Muslims) are certainly unable to accept the inheritance because they feel unfairly treated. Moreover, they feel that non-Islamic heirs are also legitimate descendants of the heirs, so they have right to obtain justice.

\footnotetext{
${ }^{9}$ Muhammad Jawad Mughniyah without years Figh Lima Mazhab translated by Masykur A.B Afif Muhammad and Idrus al-Kaff Lentera Basritama Jakarta p. 541 and 542.

${ }^{10}$ Abdul Ghofur Anshori 2012 Hukum Kewarisan Islam di Indonesia Eksistensi dan Adaptabilitas First Edition Gadjah Mada University Press Yogyakarta p. 39-40.

${ }^{11}$ Ibid.

${ }^{12}$ A. Khisni 2014 Perkembangan Pemikiran Hukum Islam (Ikhtiyar Pendidikan Doktor Membekali Calon Mujtahid Menggali Maqashid al-Syari'ah Untuk Mewujudkan Hukum Islam yang Kontekstual) First Edition Unissula Press Semarang p. 67.
} 
There are many cases related to inheritance end up in law field, such as a lawsuit filed by non-Islamic heirs to the Religious Court for not obtaining inheritance from the heirs who are his biological parents because of different religions. Thus, this problem makes the relationship between siblings become tenuous and breaks the family.

If the division of inheritance/distributable estate is determined in accordance with the Compilation of Islamic Law, it is clear that the non-Islamic heirs are not part of the inheritance due to barriers to inheritance. Cases of non-Islamic heirs claiming the same part as the heirs of the faithful will often occur and will ultimately have a bad effect on the relationship among the heirs, so there is a weakness in applying the Compilation of Islamic Law in the case of inheritance for the expert a non-Muslim heritage.

The demands of these circumstances require a renewal in the law of inheritance of Islam. Consideration for the legal protection of non-Islamic heirs is as the legitimate heir. The justice, and the mutual benefit must take precedence in the settlement of inheritance cases for non-Islamic heirs.

The legal basis in the Compilation of Islamic Laws that religious differences constitute one of the obstacles of a person to be an heir, as stated in Article 171 letter $\mathrm{c}$.

Thus, in the inheritance relationship of Islam, religious difference is one of the obstacles of a person to become an heir. Thus, non-Muslims will not be inherited as heirs of a Muslim family. In the heterogenic life, it is not possible in a family consisting of members of different families of religion. To fulfill the sense of justice as one of the principles of Islamic inheritance law, non-Muslims are actually entitled to a share of the estate in the use of a testament construction, or 'wills' if the deceased does not make a will for them. The construction of the testament is an alternative way of aiding the completion of inheritance for those who do not have inheritance, but they have close kinship with the testator. The legal aspect of providing this will is the factor of the recipient, such as to improve the system or economic condition. The juridical factor that prevents someone to become an heir can be solved by pursuing the justice factor. ${ }_{-}{ }^{13}$

Herewith are the several decisions of the religious court as well as the Supreme Court of the Republic of Indonesia related to inheritance cases between Muslim and non-Muslim heirs, among them are:

\begin{tabular}{|l|l|l|}
\hline No. & \multicolumn{1}{|c|}{ Decision Number } & \multicolumn{1}{c|}{ Case } \\
\hline 1. & $\begin{array}{l}\text { MA Decision Number : 16/K/ } \\
\text { AG/2010 from Religious courts } \\
\text { Makasar }\end{array}$ & $\begin{array}{l}\text { Heirs are Muslim (mothers and siblings) are } \\
\text { Muslim, except his non-Muslim wife gets } 1 / 2 \\
\text { share of common property }\end{array}$ \\
\hline 2. & $\begin{array}{l}\text { MA Decision Number : 51/K/ } \\
\text { AG/1999 from Religious courts } \\
\text { Yogyakarta }\end{array}$ & $\begin{array}{l}\text { Heirs and wives are Muslims, non-Muslim } \\
\text { heirs (siblings of different religions). The non- } \\
\text { Muslim heirs are inherited through the } \\
\text { mandatory will (Wasiat Wajibah) }\end{array}$ \\
\hline 3. & $\begin{array}{l}\text { MA Decision Number : 368/K/ } \\
\text { AG/1995 from Religious courts } \\
\text { Central Jakarta }\end{array}$ & $\begin{array}{l}\text { The heir is Islam, the heirs (the 5 children are } \\
\text { Islam, the } 1^{\text {st }} \text { daughter is the non-Muslim) the } \\
\text { non-Muslim heirs are inherited by the } \\
\text { mandatory will (Wasiat Wajibah). }\end{array}$ \\
\hline
\end{tabular}

${ }^{13}$ Ibid. p. 68. 
Volume 5 Issue 2, June 2018

\begin{tabular}{|c|c|c|}
\hline 4. & $\begin{array}{l}\text { MA Decision Number : } 59 / \mathrm{K} / \\
\text { AG/2001 from Religious courts } \\
\text { North Jakarta }\end{array}$ & $\begin{array}{l}\text { Heir and wife are Islam, other heirs (father of } \\
\text { heirs and siblings of non-Islamic religion). The } \\
\text { non-Muslim heirs are inherited through the } \\
\text { mandatory will (Wasiat Wajibah). }\end{array}$ \\
\hline 5. & $\begin{array}{l}\text { Decision Number : } \\
\text { 2554/Pdt.G/ 2011/PA Jakarta } \\
\text { Selatan }\end{array}$ & $\begin{array}{l}\text { Heirs are Islam and } 5 \text { children are Islam, but } \\
\text { one daughter is non-islam. The non-Muslim } \\
\text { heirs are inherited through the mandatory } \\
\text { will(Wasiat Wajibah). }\end{array}$ \\
\hline
\end{tabular}

Source: Research Report of Legal and Judicial Research Center of Law MA RI, 2016

In this case, the Compilation of Islamic Law (in the field of inheritance law) should still be developed with "Tahrij Al-Ahkam 'Ala Nash Al-Qanun" (development of the text of the law) with due regard to the social conditions of the community. In this case, it is possible in Islam which aims to benefit and at the same time negate the difficulty for human life and humanity values. ${ }^{14}$

The form of the development of inheritance law in the Compilation of Islamic Law as mentioned above, among them is a breakthrough that gives part of the inheritance to nonMuslim children that had never been done or known in practice in the Religious Courts because as opposed to the Qur'an, as-Sunnah and the Compilation of Islamic Law.

From the judgment of the Supreme Court's jurisprudence, it can be drawn the rule of law, namely that in the relation of inheritance of Islam, religious difference is not one of the barriers of a person to obtain a part of the inheritance (Muslim). To fulfill the sense of justice as one of the principles of Islamic inheritance law, non-Muslims are entitled to a share of the heirs' property by using the construction of a testament law, the "wasiat wajibah." 15

The above mentioned jurisprudence of the Supreme Court is in contrast to the legal norms that are obliterated in the Qur'an, as-Sunnah and the Compilation of Islamic Law stated by Muttafaq Alaih that: "Muslims do not inherit the property of the unbelievers, and the unbelievers do not inherit property Moslem people". In the Compilation of Islamic Law stated that: "Heirs are people at the time of death has blood relation or marriage relationship with heir, Moslem and not hesitate by law to become heir". ${ }^{16}$

The judges' decision on the development of Islamic inheritance law in the Compilation of Islamic Law can contributed in national law. The judgment of religious judiciary unearthed and the teachings or laws of Islam or the application of Islamic teachings or law will be incarnated in the form of principles of law derived from religious values, which are the way of thinking of the "religious magical" people and nation. The decision of the Supreme Court is the formation of the rule of law, which sourced and the teachings and laws of Islam became part of the national legal system. In addition, in the decision of jurisprudence, the birth or adaptation of Islamic doctrine according to Islamic teachings becomes the doctrine of the national legal system. Thus, there is no dualism between Islamic law and national law because it is fully reflected in the judgment (jurisprudence), and the product of Islamic

\footnotetext{
${ }^{14}$ Ibid.

${ }^{15}$ Ibid. p. 75.

16 Ibid.
} 
law which belongs to and enjoyed by Indonesian Muslims alone, but can also be possessed and enjoyed by other religions other than Islam called national law.

\section{Conclusion}

\subsection{Concultion}

In the Compilation of Islamic Laws, religious differences are one of the obstacles to becoming an heir. It is stated in Article 171 letter c that: "Heirs shall be persons at the time of death having a blood relation or marriage relationship with the inheritor, being Muslim and not hindered by law to be an heir". The settlement of inheritance cases against religious heirs in their contribution to the reform of Islamic law in Indonesia, ie non-Muslim heirs, is entitled to share in the estate (legacy) based on 'mustah' in order to maintain good relationships (maslahah).

\subsection{Suggestions}

In making judicial decisions, judges should more prioritize on justice and the benefit of society, not only for Muslims but also non-Muslims.

\section{References}

[1] Akhmad Khisni 2014 Perkembangan Pemikiran Hukum Islam (Ikhtiyar Pendidikan Doktor Membekali Calon Mujtahid Menggali Maqashid al-Syari'ah Untuk Mewujudkan Hukum Islam yang Kontekstual) First Edition Unissula Press Semarang.

[2] Abdul Ghofur Anshori 2012 Hukum Kewarisan Islam di Indonesia Eksistensi dan Adaptabilitas First Edition Gadjah Mada University Press Yogyakarta.

[3] Beni Ahmad Saebani 2014 Fiqh Mawaris Pustaka Setia Bandung.

[4] Mohd. Idris Ramulyo 1999 Hukum Perkawinan Islam Suatu Analisis Undang-undang Nomor 1 Tahun 1974 dan Kompilasi Hukum Islam Bumi Aksara Jakarta.

[5] Muhammad Jawad Mughniyah without years Fiqh Lima Mazhab translated by Masykur A.B Afif Muhammad and Idrus al-Kaff Lentera Basritama Jakarta.

[6] Muslich Maruzi 1981 Pokok-pokok Ilmu Waris Pustaka Amani Semarang.

[7] Sudirman Tebba 2003 Sosiologi Hukum Islam UII Press Yogyakarta.

[8] Wirjono Prodjodikoro 2006 Hukum Warisan di Indonesia Sumur Bandung Bandung. 